\title{
Sound and vision in the opening titles of Māori-language television news: A multimodal analysis of cultural hybridity
}

\section{Abstract}

Māori are the indigenous people of Aotearoa New Zealand. British settlers arrived in the 19th century with their tradition of the newspaper, and this led to a thriving Māori-language press. Today, news in te reo Māori, the Māori language, is delivered by television, radio and the internet, harnessing the conventions of Anglo-American journalism to tell stories of indigenous preoccupations (Fox 2002). The cultural hybridity that results (Grixti 2011) is particularly marked in the opening titles of Māori-language news. The musical and visual tropes of news-show mythmaking that present the news as sites of power, truth and authority are married to representations of Māori identity and beliefs to speak to a necessarily bicultural audience (A. Middleton 2020). In this paper, a multimodal approach is employed (Bignell 2002; Machin 2010; van Leeuwen 2012), which uses frame-by-frame analysis of speech, scripts, images and music to reveal the semiosis or sign processes in play in the opening titles of the country's top-rated English-language news 
bulletin, 1 News, and those of the two Māori-language television news bulletins, Te Karere and Te Käea. Analysis reveals that 1 News titles employ the sign systems common to their counterparts across Anglophone countries in the way they promote themselves as credible, all-seeing authorities. While the titles of Māori-language news opening titles retain many of the same tropes and signposts in order to be understood as a news show, they also weave in cultural references deeply embedded in Māori language and culture to represent themselves as news by and for Māori rather than the dominant culture.

Keywords: Aotearoa New Zealand; Māori-language news; news opening titles; semiosis; news music; news visuals

\section{Introduction}

Māori were the first inhabitants of Aotearoa New Zealand, migrating from the northern Pacific Ocean from 1300. They brought with them collectivist values and a highly developed oral culture organised around whakapapa, a word that refers to genealogical descent but also to the belief that all things in the natural and spiritual worlds are related and interdependent (Walter \& Reilly, 2018).

In the 1800s, British missionaries arrived, followed by settlers. Despite the British Crown and Māori signing the Treaty of Waitangi in 1840, which promised Māori "unqualified exercise of their chieftainship over their lands, villages and all their treasures", tribes were systematically dispossessed of all but a fraction of their land (Belgrave, Kawharu \& Williams, 2005, p. 391-392). Policies of cultural assimilation severely eroded Māori 
language and culture; in 1975, fewer than 5\% of Māori schoolchildren could speak their heritage language (Waitangi Tribunal, 1986).

In the 1980s, legal action by Māori under the provisions of the Treaty forced the Government to take concrete steps to protect te reo Māori and secure Māori access to broadcasting assets (J. Middleton, 2010). These moves paved the way for state-funded Māori radio and television news bulletins, with the best known of these the Television New Zealand (TVNZ) reo-Māori bulletin Te Karere, on air since 1983. The country now has three news bulletins in te reo, two on television (the aforementioned TVNZ and also Māori Television) and one on radio (Te Reo Irirangi o Waatea). Their output is also disseminated through internet platforms.

Indigenous news media are "hybrid formations" (Grixti, 2011 , p. 345) - that is, they employ western technologies to disseminate indigenous voices in culturally congruous ways. Māori journalists practice a localised version of the Anglo-American journalism tradition that allows them to use their heritage language, practise in ways that are culturally appropriate and contribute to the national agenda to revitalise te reo Māori, which is a joint responsibility between Māori and the Government (A. Middleton, 2020).

This paper begins by exploring what existing literature says about the semiosis or sign processes of AngloAmerican English-language television news titles, exploring some of its globally-recognised tropes. It then compares these to the opening titles of Aotearoa New Zealand's top-rated news bulletin, 1 News, which airs on TVNZ at $6 \mathrm{pm}$ daily. I then examine the semiosis in the titles of the two Māori-language television bulletins. The 
first is Te Karere (1983-present), that airs Monday to Friday on TVNZ. The second is Te Kāea, a seven-day show that ran on the state-funded Māori Television Service (MTS) from 2004 to early 2019. (After this time, the channel's news offerings were rebranded).

\section{Sound and vision in news opening titles: Literature review}

Around the world, television news opening titles are remarkably similar, reflecting the pervasive global influence of Anglo-American news packaging in the sound and vision used to brand a show as news, attract listener attention and establish authority (Bignell, 2002; Deaville, 2009; Thussu, 2003). See, for example, the striking similarities in this compilation of television news titles from 29 countries and a collection from Aotearoa New Zealand. Carter and Allan (2009) summed up the tropes

thus:

More often than not ... the national evening newscast commences with an image of a revolving globe (the country in question is usually highlighted) to the sound of a sharply ascending piece of theme music.

The opening sequence, having established an urgent sense of immediacy, promptly gives way to a shot of the studio, a pristine place of hard, polished surfaces (connotations of efficiency and objectivity) devoid of everyday, human (subjective) features.

The camera glides smoothly across the studio floor, coming to a halt in front of the newsreader, who is seated squarely behind a desk, his or her gaze ostensibly affixed on us. He or she is formally attired, their body movements calmly measured, with a speaking voice (inevitably a 'proper' accent) solemn and resolute in tone (p. 139). 
Various semiotic or meaning-making systems come together in news opening titles to establish the news and its presenters as trustworthy and authoritative (Bignell, 2002), making the titles a potent site of myth-making as defined by French semiotician Roland Barthes (1972): The bringing together of signs and their connotations to present a particular message that is, furthermore, presented as natural or common sense. To unpack how this is effected, I look first at music, then visual elements of news titles. All screen shots are used with permission.

\section{Music and 'newsic'}

News music is so distinctive as a global genre (Taylor, 2017) that it has earned the nickname 'newsic' (Profita, 2006), and I will examine its characteristics shortly. News music remains, however, an under-researched field, with Deaville (2009) describing the field as invisible to scholars of television news and dismissed by musicologists. But the genre has fans: There are several encyclopaedic websites dedicated to news music, among them the American sites Network News Music and the News Music Search Archive.

Certain sounds are associated with certain emotions, times in our lives, items in our social or natural surroundings and other elements of our shared human existence. Through repetition, this codal system of music becomes a shared cultural convention (Cook, 2000; Tagg, 1982; Thompson and Balkwill, 2010). Composers, whatever their culture, tap collective understandings to attempt to influence a listener's cognitive and affective state (Cook, 2000; Gorbman, 1987); musicologists such as Cooke (1959), Gorbman (1987) and Tagg (1982) have described the many connotations of musical motifs in the 
western idiom. For example, minor keys are perceived as sad and major keys as happy (Cooke, 1959). As van Leeuwen (2012) wrote, "Music fuses ideological meaning and emotion, and it is precisely therein that its power lies" (p. 325).

News themes often open with a forceful brass-and-drum fanfare (Burwell, 2003) that marks the boundary between the previous genre and the news. This auditory cue is "designed to attract the viewer's attention from other domestic activities, and to signal the urgency of news reporting as time-bound activity" (Cubitt, 2006, p. 4). The come-here message is commercially necessary: News is expensive to make and "must produce an audience that is of the right size and composition to be sold to advertisers" (Fiske, 2010, p. 283).

The power of brass and drums lies in the semiosis of their sound through the ages, as Burwell (2003) wrote:

The two loudest instrument groups in the Western orchestra are the brass and drums, so it should come as no surprise that they have both served for centuries as long-distance communications devices, not only in the West but all around the world. Before metals could be worked to form brass instruments, animal horns were used for the same purpose - shofar in the Middle East [made from a ram's horn], conch shell in the Pacific, ox horn in medieval Europe. By the 9th century in Europe, horns had become associated with the military and nobility, and that association is still with us today (para. 20).

Brass and drum sounds in news titles today are usually synthesised (Machin, 2010), but the association persists. In adopting the musical signifiers of the military and nobility, the news enrobes itself in a Barthesian mythical cloak that in European-derived cultures bears 
connotations of power, authority and status. In doing so, it frames the viewer as a member of a select group: "A member of the cosmopolitan elite, whose fingers are always on the pulse, and whose interests are not restricted to the local" (Cubitt, 2006, p. 4).

Other common elements of news music include a major ("happy") key that tends to employ a rising melody using large intervals - that is, wide leaps upwards to higher pitches that are heard as dynamic and active (Cooke, 1959) and heroic and masculine (van Leeuwen, 2012). The melody often features syncopation, when a rhythm that typically occurs on strong beats lands instead on weak beats, an aspect that is more pleasurably received by the human ear than unsyncopated patterns (Keller and Schubert, 2011). Beneath is a driving, steady, and uniformly patterned $4 / 4$ bass beat. Overall, the soundscape creates a sense of controlled urgency (Taylor, 2017). The message: It's a dramatic world out there, but we're in control.

However, there is another sound that belongs to the tropes of news music, but which is, perhaps, less obvious. The clattering, urgent rhythm of the teletype, also known as the teleprinter, draws attention to the process of newsgathering (Eldridge \& Philo, 1995). For most of the $20^{\text {th }}$ century, until newsroom computerisation made it redundant, the teletype machine received incoming news and printed it out on continuous rolls of paper (Burwell, 2003; Profita, 2006). The machines' clacking was so distinctive that from the 1960s, radio and television news shows, among them the CBS Evening News, opened with nothing more elaborate that its clatter under a voice-over (Deaville, 2009; see a clip here). 
The advantage of the teletype sound was its lack of "semantic baggage" (Burwell, 2003, p. 19); at that time, television executives resisted adding music to the news, "fearful of adding an emotional element to what they regarded as the objective reporting of the day's events" (Deaville, 2009, p. 613). As times changed and composed music became an essential component of the call to attention, the teletype sound, or a musical elaboration, remained (Deaville, 2009). See, for example, the theme for CBS Evening News 1982-1987, and, in 1989, the opening seconds of the first broadcast of 3 National News in Aotearoa New Zealand.

\section{Visuals}

News-production research makes passing reference to the design of opening titles (L. Cooke, 2005). However, like any televisual communication, the opening images convey a narrative that frames the news show and its consumers. News titles are graphics-led in the $21^{\text {st }}$ century, with fast-moving, dynamic images that suggest "technological sophistication and contemporaneity" (Bignell, 2002, p. 113). As well as providing a consistent brand identity, the visuals project the idea that what is to come is of importance; they employ various motifs and clichés to imply authority. A common device is the globe, alongside symbols of capitalist democratic economies such as clocks, maps, and cityscapes (Cubitt, 2006; Lloyd, 2002). We focus here on the image of the globe, as it is a common feature of news titles and an element in two analyses to come.

The globe is often represented as a graphic and rendered as if seen from afar (Machin \& Polzer, 2015), with the viewer in a high-angle position of omniscience in deep 
space. From this viewpoint, the globe spins and moves, representing the news as "about rapid movement, but not so quick that it is chaotic" (Machin \& Polzer, 2015, p. 145). Often, this abstracted globe is transparent, suggesting "something more easily graspable, open and honest" than a photographed Earth (Machin \& Polzer, 2015, p. 144). In exploring ideology and news, Cubitt described this presentation of the globe "as a skin whose further side remains in view" (2006, p. 24); from here, we see:

the undifferentiated flux of human activity, which news reporting will draw into an objectifiable unity that can be addressed as content: As stories, as graphics, as maps. Thus the achievement, in ideological terms, is not the centering of the viewer, who is in any case presumed to be dispersed, but the centering of the world as a single entity which can be described, spoken of or about, argued over (Cubitt, 2006, p. 9).

The connotation is that our vast planet and its inhabitants are interpretable and the Earth borderless, thanks to the reporters working on our behalf (Cubitt, 2006).

Opening sequences inevitably come to rest on presenters, whom Morse (1998, p. 42) described as "a special kind of star supported by subdued sartorial and acting codes that convey sincerity". As the physical manifestation of the news, presenters must reinforce its projection of power and calm control with "visual authority, voice, poise, movement and that hard-to-define but recognisable quality of charisma" (Boyd, Stewart \& Alexander, 2012, p. 338).

The on-screen world of presenters is professional and corporate. They are often seated behind large desks, 
where they resemble powerful executives to whose office the viewer has been summoned (Graddol, 1994). Presenters are often described as "news anchors", and indeed, the very phrase suggests stability in a turbulent world (Selby and Cowdery, 1995). In addition, presenters' voices, impersonal and neutral, reflecting the formal, official styles of speech to which we are attuned (van Leeuwen, 1999).

News presenters are evenly lit so they have, quite literally, nothing to hide. As Graddol (1994) noted, lighting in film and television is a semiotic channel. Studio lighting avoids shadows, which would "connote an emotional dimension and undermine the attempt to represent as dispassionate the portrayal of the world which is being offered" (1994, p. 148). The fact that presenters are invariably live-to-air in opening titles aims to establish a sense that the news to come is also live, although the items that follow have been pre-recorded (Allan, 2010; Machin \& Polzer, 2015). Here, the myth created is immediacy - that this news has only just come to hand.

\section{Methodology and methods}

Kaupapa Māori

The overarching paradigm informing this paper is Kaupapa Māori. This can be summarised as research by Māori, about Māori that centres Māori knowledge, perspectives, language and cultural norms. In ontological terms, the Māori worldview is tribal and collective, with the physical and the metaphysical viewed as an indivisible whole. We see ourselves as children of the primal parents, Ranginui the sky father and Papatūānuku the earth mother, and are, therefore, directly related to everything in the natural environment. 
Our epistemology, called mātauranga Māori or Māori knowledge, is transferred intergenerationally, encoded in a rich and extensive oral culture (Henry \& Pene, 2001; Pihama et al., 2004; Smith, 2012).

Most importantly, the Kaupapa Māori paradigm recognises that Māori live in a colonised country where reclaiming our language and identity has involved claiming the tools of the colonising powers to serve our aspirations, as has been seen in the development of Māori-language and Māori-interest media (J. Middleton, 2010). The paradigm also recognises that many Māori, like this researcher, are "necessarily bicultural" (Holmes, 2003, p. 133), moving between mainstream and indigenous worlds. Thus, Kaupapa Māori "weaves in and out of Māori cultural beliefs and values; western ways of knowing, Māori histories and experiences under colonialism, western forms of education, Māori aspirations and socio-economic needs, and western economies and global politics" (Smith, 2012, p. 193). In terms of this analysis, this means that the researcher brings to bear a semiotic awareness (Kern, 2015) informed by both Pākehā and Māori worldviews.

Modes and multimodal analysis

A mode is a type of communication, and can include written texts, spoken words, still and moving images, sound, gestures, colour and touch (Bezemer, 2014; Flewitt et al., 2009; Jewitt, 2009). Here, we are primarily concerned with music, moving images, the human voice, colour, graphics and framing - a multiplicity of modes that interact and interplay in dynamic and creative ways to convey meaning. From multimodal data we gain: 
a dynamic constellation of resources, where meanings are produced through the inter-relationships between and within the data sets, permitting the researcher literally and metaphorically to 'zoom in' on fine-grained detail and to pan out to gain a broader, socially and culturally situated perspective (Flewitt et al., 2009, p. 44).

The principal analytical tools applied for the purposes of this paper are semiotic analysis, intertextual analysis and musical analysis. Semiotics is the study of cultural signs and symbols and how they are used and interpreted in different contexts (Bignell, 2002; Machin, 2007, 2010, 2011). Intertextual analysis focuses on the shaping of a text by an earlier text (Allen, 2011; Bakhtin, 1986; Fairclough, 2003). Musical analysis (van Leeuwen, 2012; 2017) calls on the author's education in music in both western and indigenous settings. Finally, applied to all the above is an interpretative lens reflecting the situated knowledge (Haraway, 1991) and self-reflexivity (Creswell, 2013) of the author, a culturally connected Māori woman who speaks te reo Māori, and who is a kaupapa Māori researcher and professional journalist. With this toolkit, I set out to ask the following: How are meanings being made, reinforced and transformed in the three sets of news-show opening titles?

\section{Data}

The day on which data was gathered, Friday, August 25, 2017, was chosen at random, with the opening titles of the three programmes recorded with screen-capture software. The opening titles are the same for every edition of the shows, apart from the teases, the inserted promotions of upcoming stories. Following the example of (Tan, 2014), a table was drawn up in order to record, 
frame by frame, each image and its associated modes: visual, aural, colour, textual, cultural and musical (Figure

$1)$.

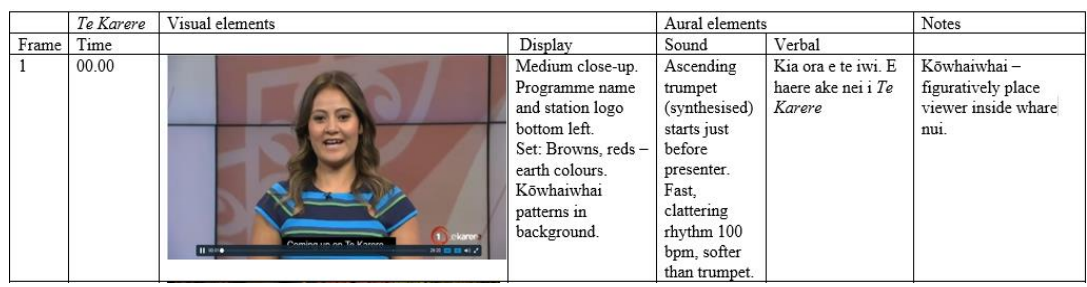

Figure 1. An example of the matrix.

Now, I explore how the semiotics of global news are reproduced in 1 News.

\section{Analysis}

\section{News}

The opening titles of 1 News closely follow the tropes and traditions of Anglo-American news branding while using images of Aotearoa New Zealand to clearly situate the bulletin. On this day, the titles proper were preceded by the weather presenter giving a 20 s rundown on the day's conditions while standing before a graphic of the Earth rather than a weather map, the perspective a fly-over of Aotearoa New Zealand from south to north (Figure 2). 


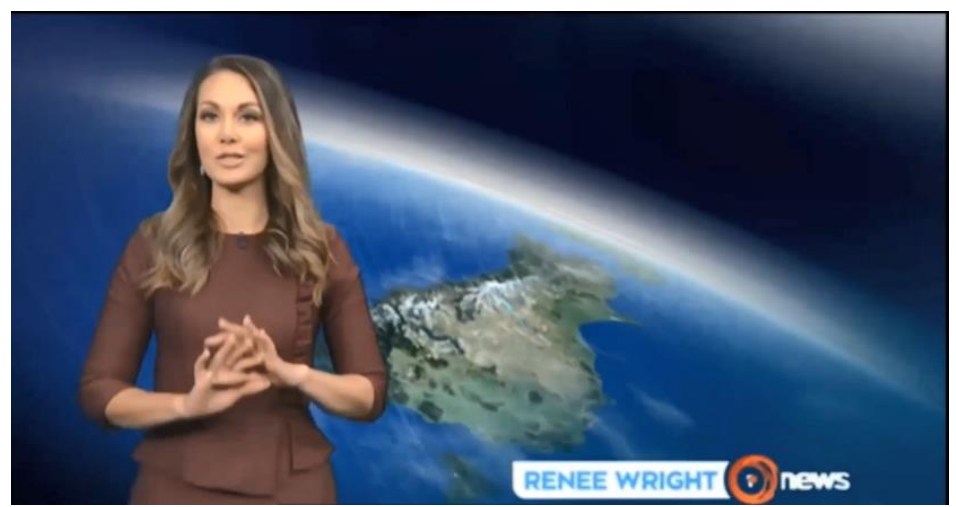

Figure 2: A $20 \mathrm{~s}$ weather wrap preceded the opening titles of 1 News.

In the titles themselves (Figures 3-6 and 9), the scenes captured are wide-angle and speak of the manmade environment: a lighthouse at Castle Point, Wairarapa; cranes at a port; concrete silo in a park in Auckland's central business district and, finally, an aerial shot of the inner city. All are accelerated tracking shots.

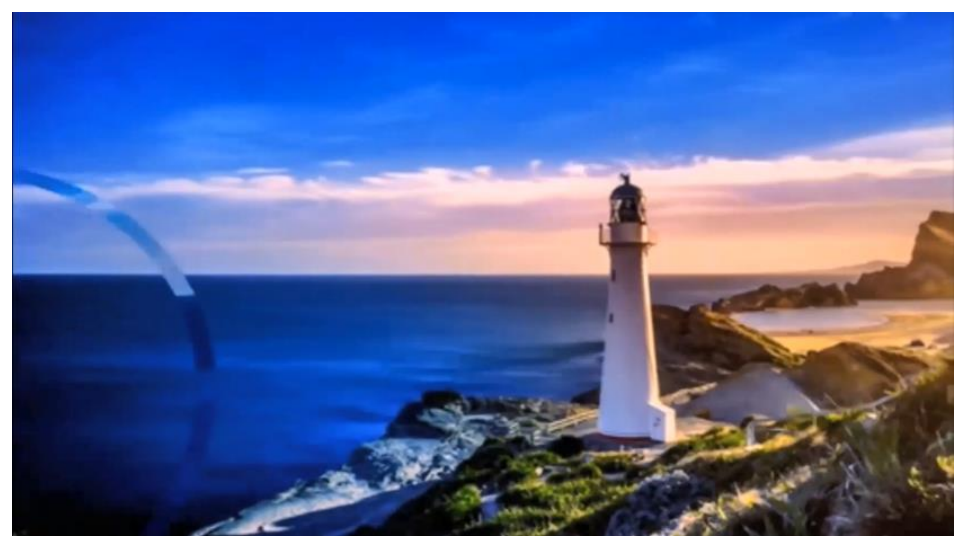

Figure 3: Castlepoint lighthouse, Wairarapa. 


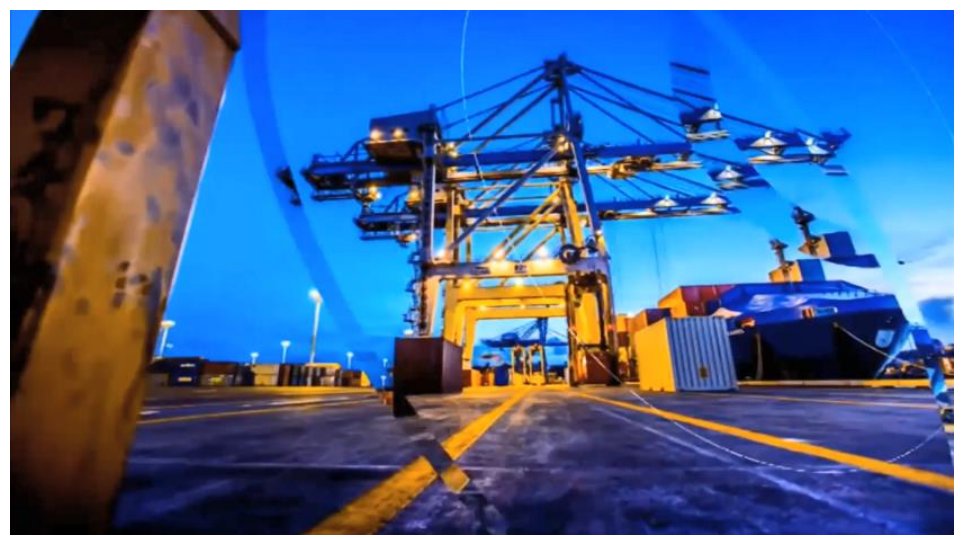

Figure 4: Cranes at a port.

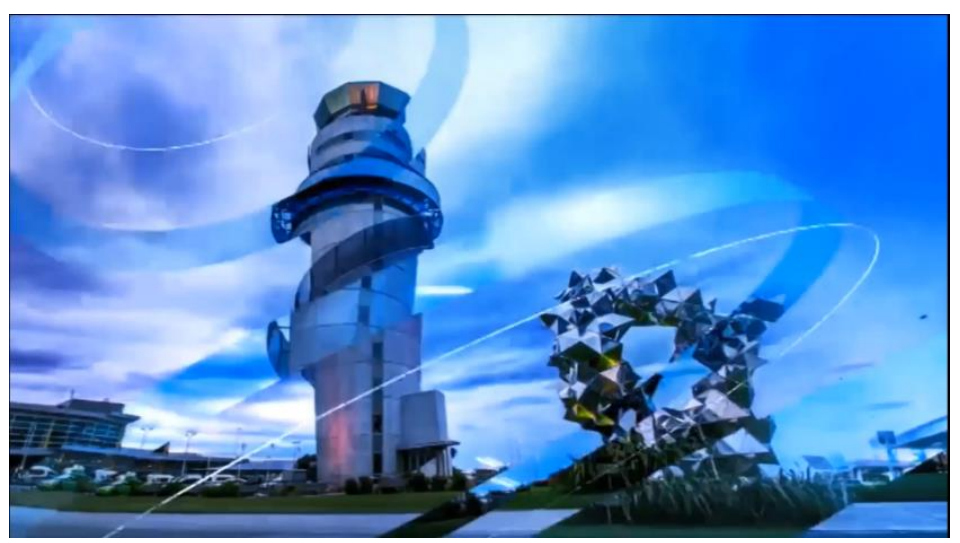

Figure 5: Silo at an inner-city park. 


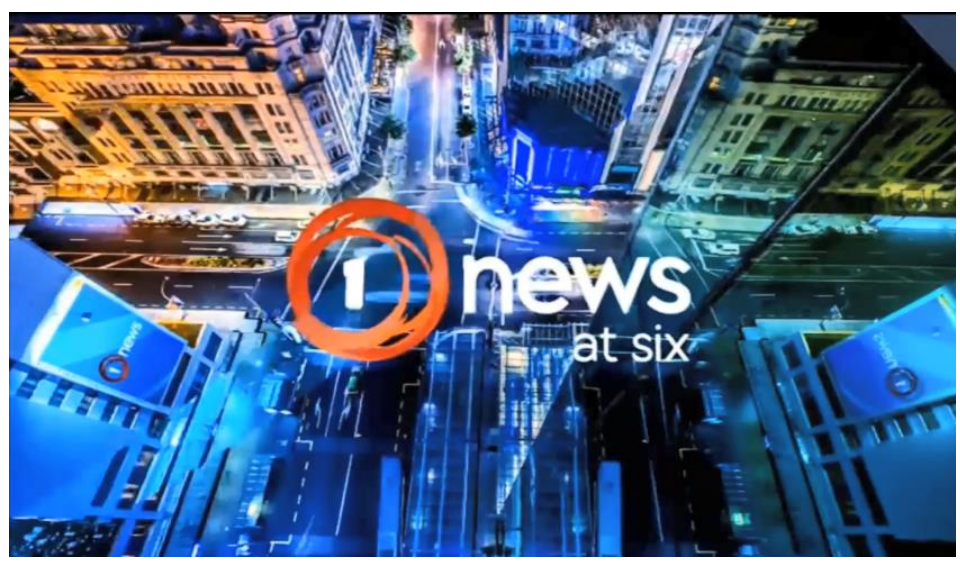

Figure 6: Aerial shot of the city centre.

Colour is also a semiotic resource; colour, culture and context interplay to produce meaning. Colour can have a direct value, such as dark, or light; and/or an associative value - that is, a psychological response in that a colour may evoke certain associations (Kandinsky, 2010; Kress $\&$ Van Leeuwen, 2002). Throughout 1 News titles, the primary colour is a rich, saturated blue. Cross-cultural research suggests that in the Anglo-Saxon world - that is, the cultures derived from Great Britain - blue is associated with high quality, corporate and masculine. Here, colour reinforces the authority for which news shows strive (Aslam, 2006).

Another important aspect is the concentric rings in Figures 3-5, which form part of the branding of all TVNZ channels (see Figure 7). In all TVNZ news-show opening titles, these rings move diagonally from both right and left sides of the frame to increase a sense of fluid movement. Titles also switch between teases with a graphic 
'Sound and vision in the opening titles of Māori-language television 17 news'

treatment that employs the curves of the rings to produce a reveal-style transition, as in Figure. 8.

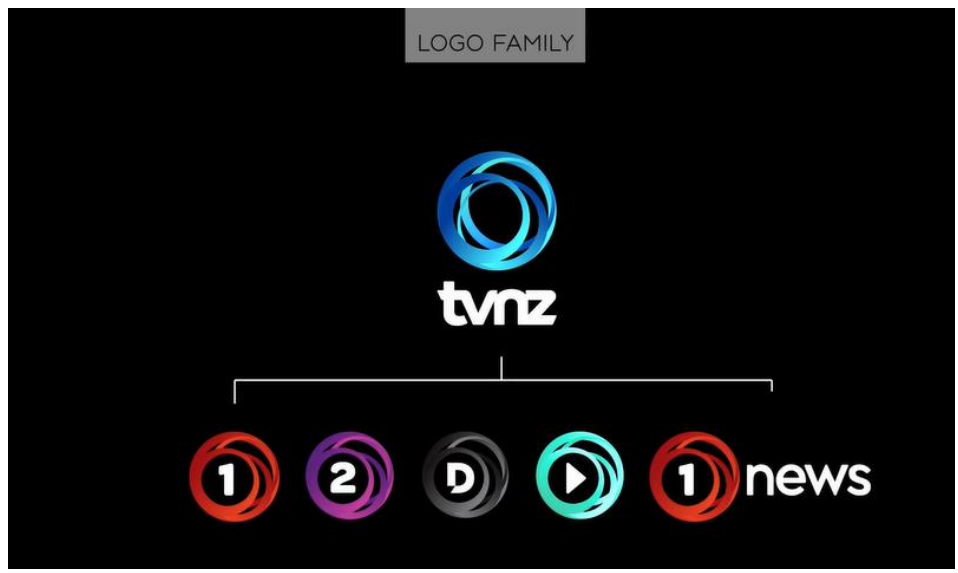

Figure 7: The TVNZ brand family, showing the blue primary logo and those for its offerings, from left to right TV1, TV2, Duke, On-Demand, and 1 News.

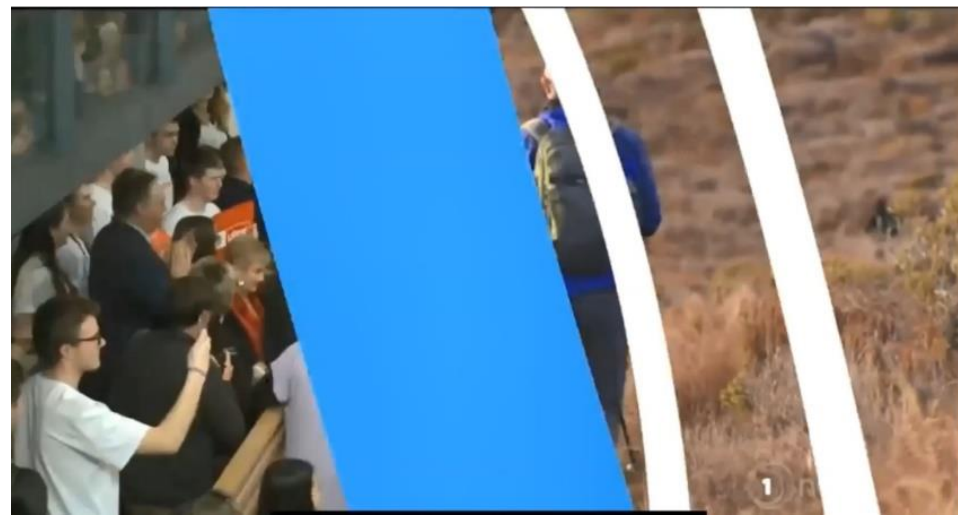

Figure 8: The concentric rings used as a transition between teases on 1 News. 
The rings refer to the fact that concentric circles have long been the international visual shorthand for the electromagnetic waves that transmit radio, television and internet data (Born, 2015; Lloyd, 2002; J. Slack, personal communication, September 16, 2018).

The typography of news titles is generally uncluttered sans serif typefaces (Eldridge \& Philo, 1995). Large, angular capitals infer authority and grab attention, with softer rounded fonts seen as gentler and more feminine (Machin, 2007). Here, the curves of the TVNZ typeface reflect the circular forms of the corporate branding used across all its shows (TVNZ Brand Guide, n.d.; Venuto, 2016).

After the final teaser, the titles switch to a long shot of the two presenters, a woman and a man. Their formal demeanour suggests that something important is about to happen: they are seated and square to the camera behind their glossy desk. The set embodies competence and order - the surfaces are pristine and glossy; the table is bare. The message is clear: the news journey of the day, no matter how frantic and messy behind the scenes, comes to calm, controlled fruition here (Selby \& Cowdery, 1995). 


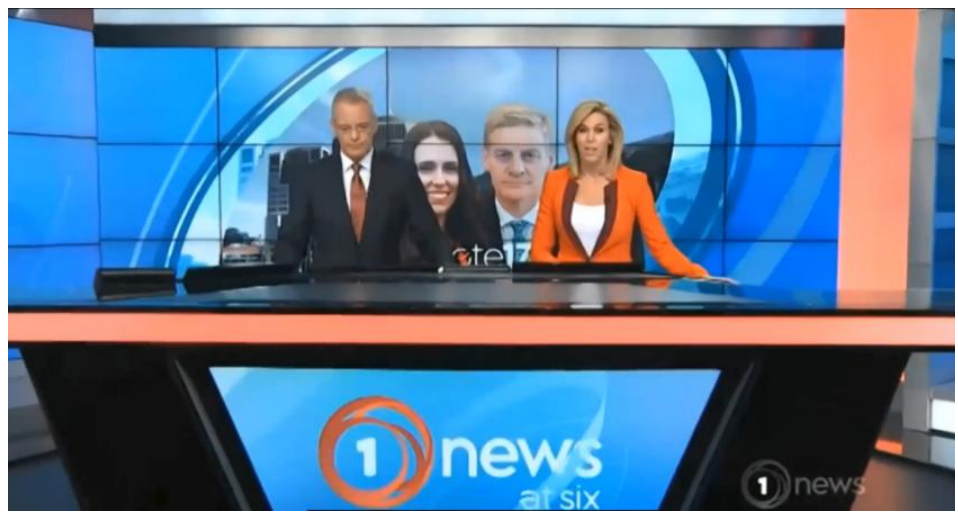

Figure 9: Presenters Simon Dallow and Wendy Petrie.

Musically, the 1 News theme, which can be heard without teases here, is a standard news theme in the AngloAmerican tradition. It begins with ascending, synthesised trumpets in a major key. A timpani strike, signifying gravity and importance (Machin, 2010), introduces an onthe-beat bass rhythm in 4/4 that, in terms of tempo, matches the military marching beat of $120 \mathrm{bpm}$ (Randel, 2003). A lighter, syncopated rhythm is reminiscent of the teletype machine.

During two teases, the music diminishes to what news composers call a bed (Deaville, 2007) so the teases are audible. During these teases, a low, cello-like sound can be heard emphasising the first beat of every bar, sometimes accompanied by a timpani strike, to maintain the military precision of the tempo. Also heard in the bed are two recurring electronic beeps and a muted, electronic reprise of the opening trumpet tune, both of which underline the highly digital nature of this news world. This, then, is an opening sequence that reflects the 
entrenched semiotics of Anglo-American news communication.

Te Karere

Te Karere translates as the messenger (Fox, 2002). The opening titles begin with a medium close-up, eye-level shot of the presenter, whose demeanour speaks of an approachable professionalism (Figure 10). This shot size is considered to be emotionally neutral and thus is widely used for factual presentation (McCuhil, n.d.).

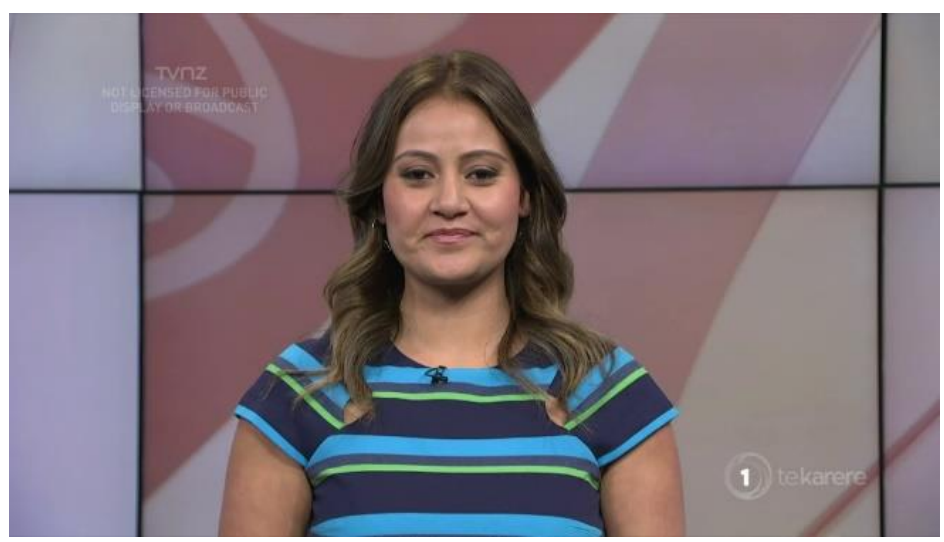

Figure 10. The opening frame of Te Karere titles, with Irena Smith presenting.

The general colour palette for Te Karere is earthy browns and reds set against white; such browns and reds are standard colours on the exterior of whare nui, or Māori meeting houses (Figure 11). The presenter says "E haere ake nei i Te Karere" [coming up on Te Karere] in a neutral tone. Behind her on the video wall, moving diagonally, are red-brown, rectangular bands bearing curved shapes that strongly resemble painted scroll designs known as 
kōwhaiwhai. These designs are found on the exposed interior rafters inside whare nui (Figure 12); kōwhaiwhai designs commonly represent tribal genealogy (Adsett, Graham \& McGregor, 1992; Hamilton, 1901; Higgins \& Moorfield, 2004) (Figure 13). Here, the kōwhaiwhai patterns behind the presenter figuratively place both presenter and spectator inside the primary communal space in Māori life.

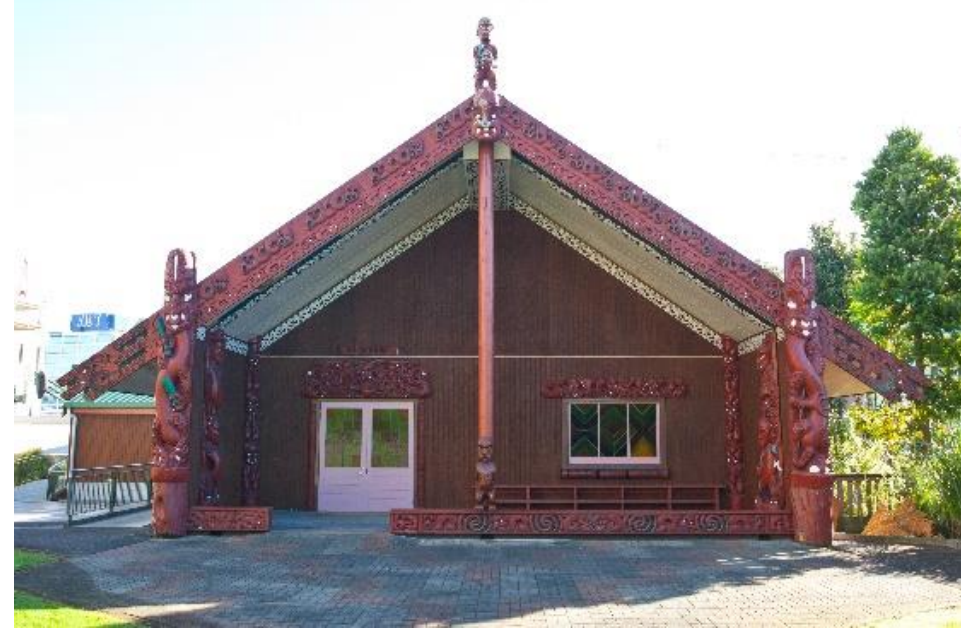

Figure 11: The exterior of a typical whare nui (meeting house). This is Te Pūrengi, the whare nui at Auckland University of Technology. 


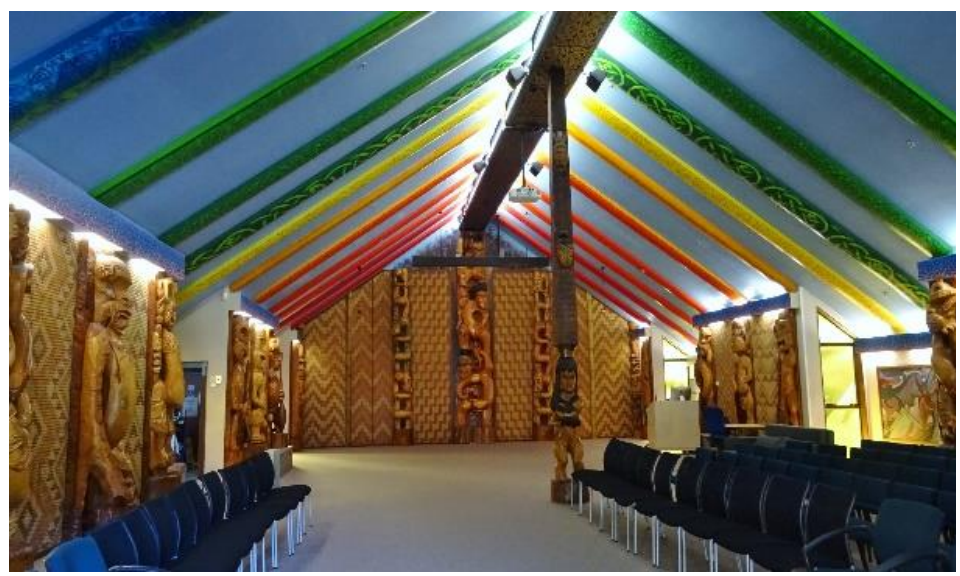

Figure 12: The interior of the whare nui Te Pūrengi, showing the exposed, decorated rafters.

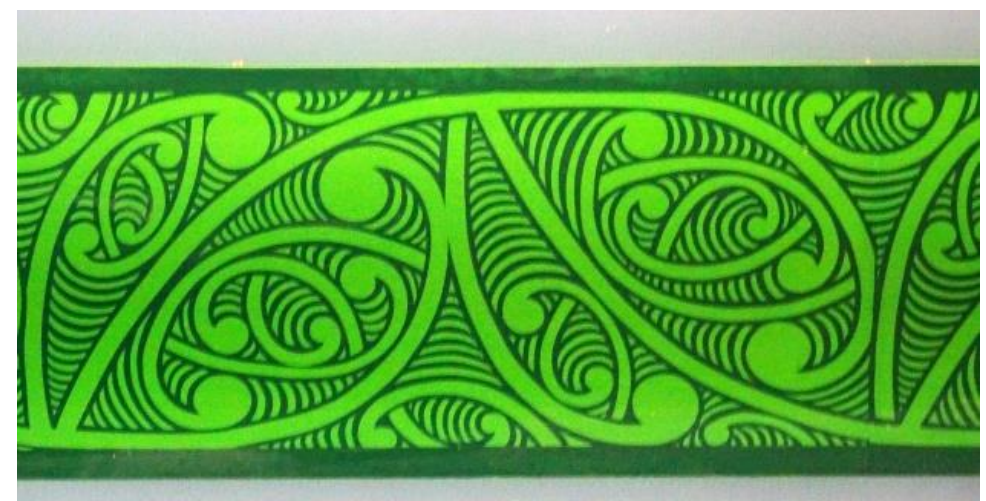

Figure 13: A close-up of a kōwhaiwhai panel inside the whare nui Te Pūrengi.

The music begins as a standard news theme: a syncopated, ascending, electronic trumpet-like sound in a major key and a steady tempo of 100 beats per minute (bpm). In the background, fast snare drum-type beats clatter, an echo of the teletype machine. 
As teases run, we hear male voices shouting "hî̀!" (pronounced hee) periodically. The utterance "hīl" is an intertextual borrowing (Allen, 2011; Bakhtin, 1986; Fairclough, 2003) associated with mau rākau, or the use of Māori weaponry, and haka, a posture dance with chant performed by warriors to energise them before battle and display an intimidating athleticism (Gardiner, 2007; Kāretu, 1993). Outside Aotearoa New Zealand, the haka is possibly best understood as the dance performed by the national rugby team, the All Blacks. The word "hī!" is not translatable but serves to raise adrenaline and project power ('The haka: New Zealand icon', n.d). The association, then, is of a vigorous, Māori, male energy. As the last tease ends, the theme reprises and climbs to an anthemic swell. We hear another intertextual borrowing in the sentry's call of ancient times: "Kia hiwa rā!" This means "Be alert!" and was shouted around Māori settlements at night to reassure inhabitants that they were safe and, critically, to warn off would-be attackers (Rewi, 2004; 2010). Today, this phrase is often a prelude to a formal speech and serves to focus listener attention (Rewi, 2010). Here, it has transferred into a new medium but serves the same function.

TVNZ commissioned the title music. The brief, said design director Jacob Slack, was to:

Create something that had the urgency and seriousness of a news bulletin but layering it with traditional Māori instruments and vocals, because vocals are so important in Māori music. We also decided on the shout at the end as a call to action (J. Slack, personal communication, July 10, 2018). 
Freelance composer Jim Hall said he aimed to write a "forceful" and urgent theme that would "sound like an important news programme with a Māori flavour". To that end, he said, it contained what he called the "clichés of news music", here exemplified by the brass-like fanfare, the teleprinter echo and the sense of urgency. As Hall is not Māori, he consulted Māori staff about the indigenous elements (J. Hall, personal communication, July 12, 2018).

As the theme plays, four images create a time-lapse of the day. As in the 1 News titles, the shots are wide-angle accelerated tracking shots. The sense of energy is accentuated by the simultaneous, diagonal movement of TVNZ's signature rings. The predominant colour is a saturated red-brown, once again reflecting the predominant colours of whare nui. However, these are not images speaking of capitalism and cities as do the titles for 1 News. The first shot in Te Karere titles (Figure 14) shows the sun rising from the top of Hikurangi, the $1750 \mathrm{~m}$ East Coast mountain that is sacred to the Ngāti Porou tribe. The peak is believed to be the first mountain in Aotearoa New Zealand to see the sun rise (Reedy, 2009). 


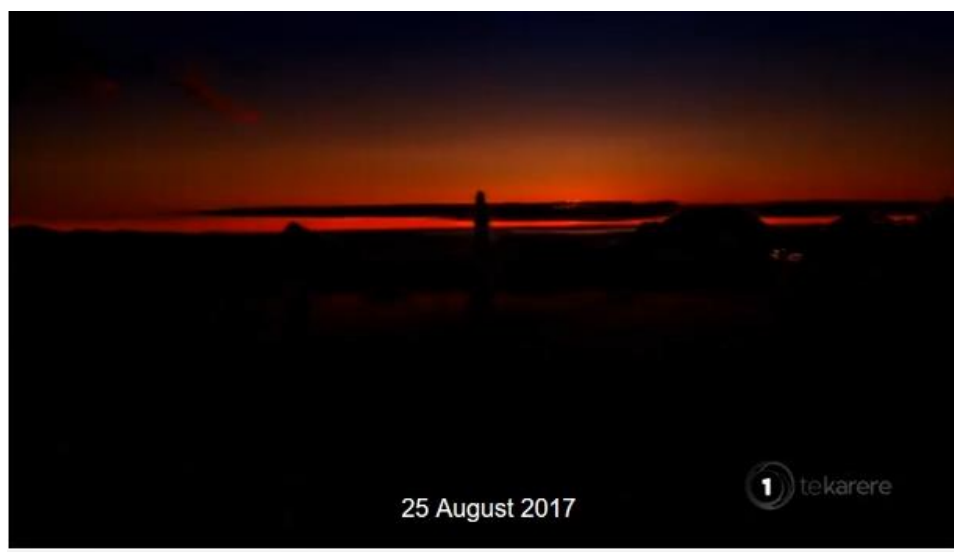

Figure 14: The first frame of Te Karere titles depicts dawn at Hikurangi mountain, North Island.

Mountains feature heavily in Māori life, language and history; they have mana, or authority, and represent strength, power and omniscience. In formal oratory, people may be favourably likened to a lofty mountain (Middleton, 2020). Most tribes have a maunga tapu, or sacred mountain (Orbell, 1985) that forms an important plank of individual and collective identity. When making a formal public introduction in te reo, called a pepeha (Rewi, 2010), Māori will name the landmarks of that identity, usually starting with the mountain and body of water that locate the tribe geographically. A pepeha will also name the migratory canoe that brought a tribe's founding ancestors from East Polynesia to Aotearoa New Zealand during the $14^{\text {th }}$ century (Walter \& Reilly, 2018; Williams, 2004) and also the tribe's marae, the place where their whare nui stands.

The second image (Figure 15) brings us to the latter. It is a low-angle capture of Tamatekapua, the tribal meeting 
house at Te Papaiouru Marae in Rotorua, which is home to Ngāti Whakaue subtribes Ngāti Tae-o-Tū and Ngāti Tūnohopū. Tamatekapua was the captain of the Te Arawa migratory canoe (Mitira, 1944) and this meeting house embodies him; in his figurative belly his descendants gather (most meeting houses in Aotearoa New Zealand represent an ancestor). Such an image reinforces the primacy of blood ties and the central place of the marae in Māori life.

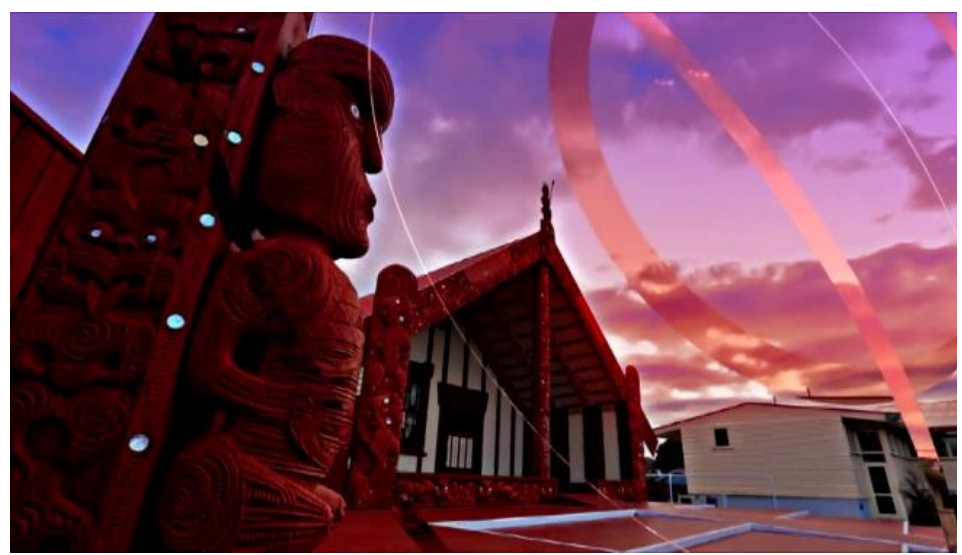

Figure 15: Te Papaiouru Marae, Rotorua.

The vision then segues to the South Island's Lake Matheson (Figure 16) in which is reflected the mountain Aoraki, the highest peak in the country and sacred to the Ngāi Tahu tribe. Here we have water and mountain together; the titles have thus far presented us with mountain, water and marae, three important elements of pepeha (Rewi, 2010). We might speculate the creators knew this when they created the titles - but it turns out that this wasn't the case. 


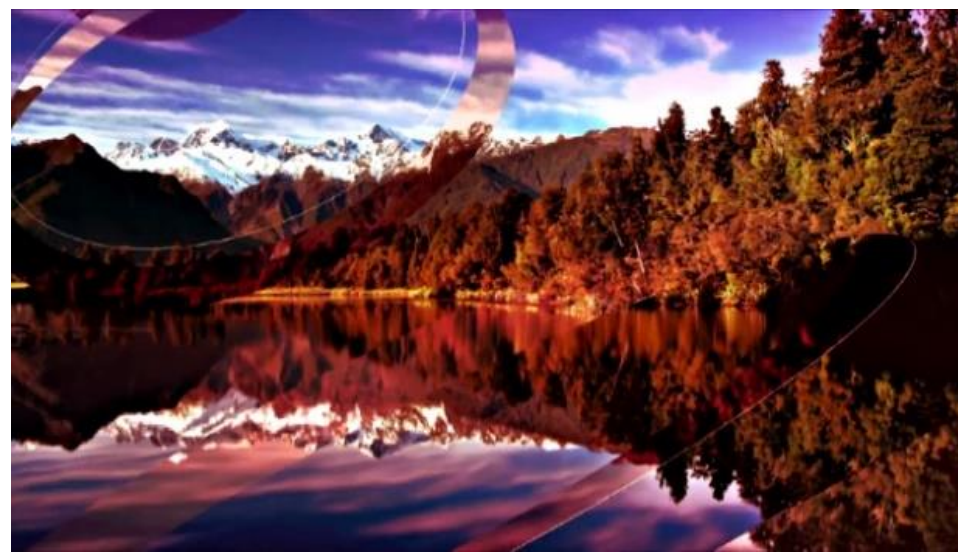

Figure 16: The mountain Aoraki reflected in Lake Matheson, South Island, with moving rings visible.

It appears that TVNZ staff chose the elements of a pepeha for Te Karere opening titles without being conscious of the symbolism - that is, there was a gap in semiotic awareness (Kern, 2015) in this area. When it was suggested that the titles could be read as representing a pepeha, design director Jacob Slack, who is non-Māori but who knew what a pepeha was, expressed surprise. "It totally is (a pepeha) but I have never even thought about that." The idea, he said, was to shoot landscapes that were accessible and "significant to Māori" within a tight budget. Te Karere staff, who are all Māori, made suggestions on locations; however, no unifying metaphor was suggested nor planned (J. Slack, personal communication, September 16, 2019).

The final image in the title sequence (Figure 17) is a twilight, low-angle shot of the tekoteko, the carved figure on the gable of the meeting house at the Auckland University of Technology. The Sky Tower, an $328 \mathrm{~m}$ landmark opened in 1997, looms behind. 


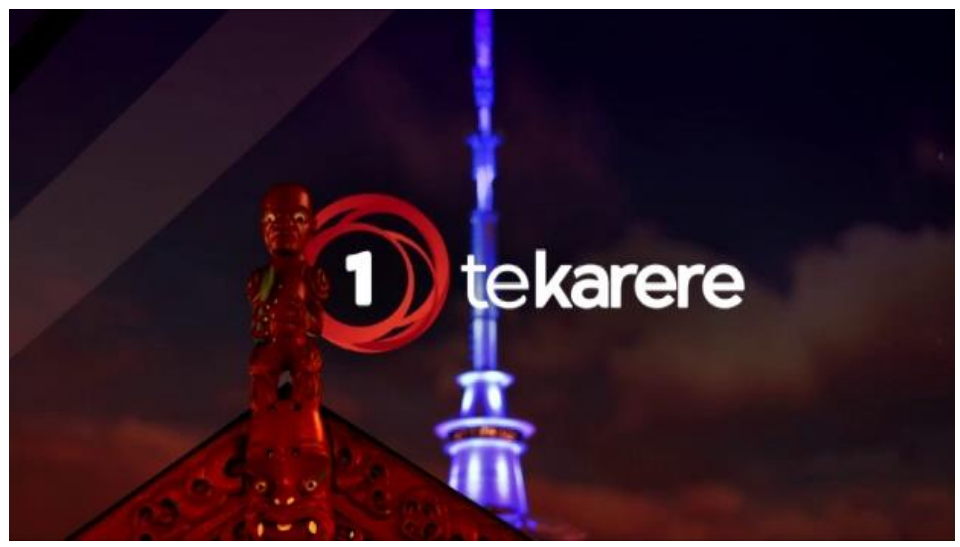

Figure 17: Auckland University of Technology marae and the Sky Tower, moving ring just visible top left.

The meeting house, named Te Pūrengi, is a modern conceptualisation of a whare nui; it belongs to an educational institution rather than a tribe, its users linked by their pursuit of education rather than genealogy. This tekoteko represents Tìtahi, a noted historical figure of the local tribe Ngāti Whātua, and his presence records that this whare nui, although owned by the university, sits on Ngāti Whātua's ancestral lands (Auckland University of Technology, n.d.). Tekoteko confer protection and guardianship, which is they have bulging eyes and carry a weapon.

The low-angle shot places an ancient expression of Māori culture and the modern Sky Tower in a dominant position over the viewer. Together, tekoteko and tower signify that tradition and modernity are both parts of Māori life. 
According to Te Karere executive editor Arana Taumata, the pair create a strong closing image for a show "that strives to uphold the Māori worldview in contemporary times". The programme name, accompanied by the channel logo, appear on screen, then fade out.

Finally, the titles show a wide shot of the studio (Figure 18), with the presenter standing side-on and at some distance from the viewers as the camera moves closer. The viewer is placed in the whare with the presenter, rather than facing a presenter square-on to the spectator from behind a desk. It's the sort of view you might have if seated in a whare nui listening to oratory.

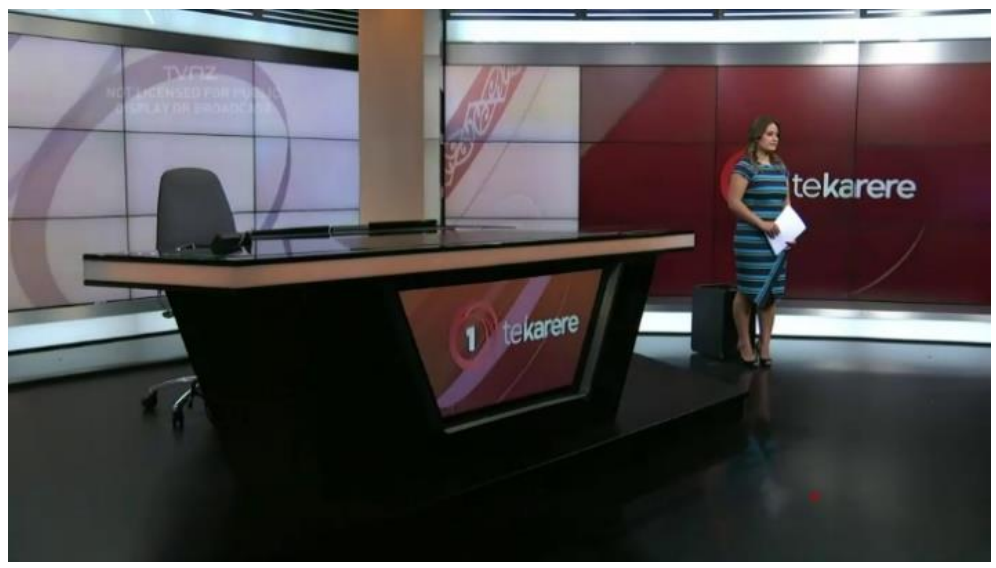

Figure 18: Wide shot, Te Karere studio.

Te Karere titles then remove the desk altogether, switching to the presenter in a medium long shot. She greets the audience with a steady gaze and " $\mathrm{E}$ aku huia kaikawaka, tēnā koutou katoa" (Figure 19). 


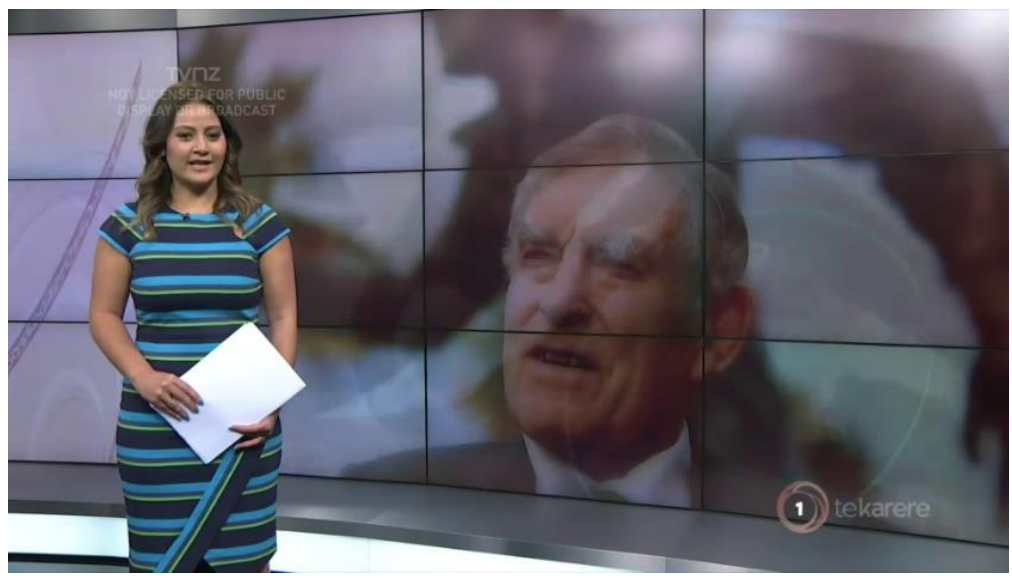

Figure 19: Final frame of titles. The late Sir Colin Meads is on the video wall.

This translates as "my huia birds that consume my heart, I acknowledge you". The huia, now extinct, was large and black with orange wattles, a white beak and 12 long, white-tipped tail feathers that it would spread in display. These tail feathers were prized as headwear denoting rank and were so valuable that they were passed from one owner to the next (Orbell, 1985).

The phrase "E aku huia kaimanawa, tēnā koutou katoa" is a whakatauki $\overline{1}$, or saying, often heard in formal oratory, which remains an important art form in the Māori world (Rewi, 2010). Formal address to people often draws favourable comparisons to valued landmarks and birds (Orbell, 1985), and such phrases act to figuratively ennoble listeners. This, then, is an intertextual borrowing from oratory that has transferred into news framing and presentation (see Middleton, 2020, for other examples). The titles, which last $1 \mathrm{~min} 3 \mathrm{~s}$, end here as the presenter introduces the first story. 


\section{Te Kāea}

The show's name comes from the kāea, a trumpet up to $2 \mathrm{~m}$ long, made of resonant wood with a large mouth and possessing a carrying, bugle-like call. Kāea, also known as pūkāea, were used in the past to assemble the people, signal in times of war, or give the alarm (Best, 1976; Flintoff, 2004).

Te Kãea titles open with a cymbal shimmer followed by a real kāea issuing a held note that then falls a tone; here is our call to action, delivered in a Māori idiom. Underneath, an urgent, 4/4 pattern runs at a brisk 130 bpm with percussive accents reminiscent of the teleprinter's chatter. Composer Joel Haines wrote with a brief, he said, to provide a "listen-to-me" sound. He prepared by listening to a range of news music to fill his head "with the sounds and devices of the genre". Haines is not Māori, so asked a Māori musician to advise him on Māori elements (J. Haines, personal communication, July 9, 2018).

In the opening frame (Fig, 18), a graphically rendered, transparent globe turns, the continents rendered in square, white blocks. The perspective is an omniscient high angle. The dominant colour in this frame and through the titles is a bright, saturated blue. The typography of news titles is generally modern, uncluttered sans serif typefaces (Eldridge \& Philo, 1995), and such is the case here, with the show's name and the date in bold, upright capitals that dominate the screen and our attention (Machin 2007). 


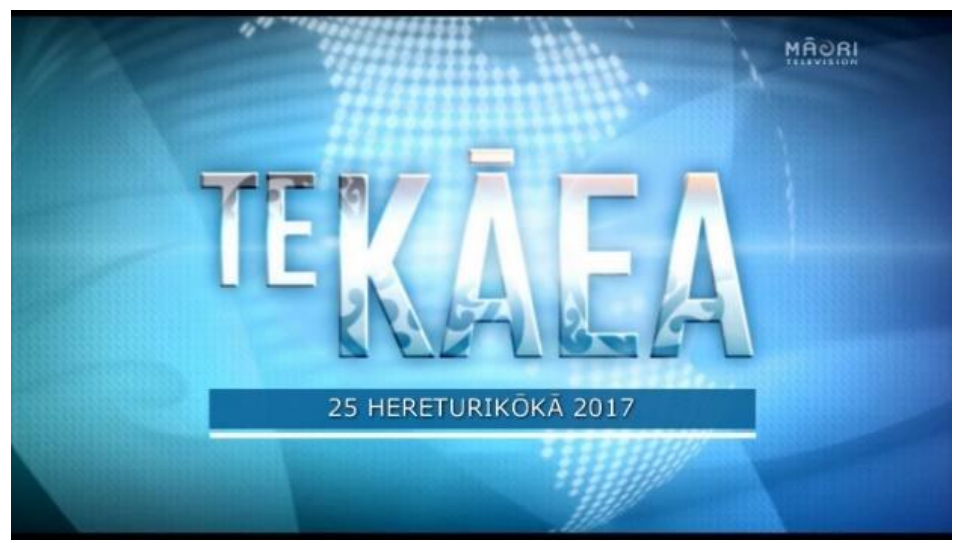

Figure 20: Opening graphic, Te Kāea.

The capital letters are inlaid with the symmetrical, curved designs of kowwhaiwhai, once again placing the viewer figuratively in a Māori space (Figure 20). These particular designs denote the mangōpare or hammerhead shark (Sphyrna lewini) (Mulholland \& Bargh, 2015), a creature known to Māori as having great strength, determination and tenacity (Figure 21). Its evocation here, according to Māori Television designer Luiz Bond, aimed to apply these traits to Te Kāea and its staff (L. Bond, personal communication,

$$
\text { July }
$$

13 , 2018).
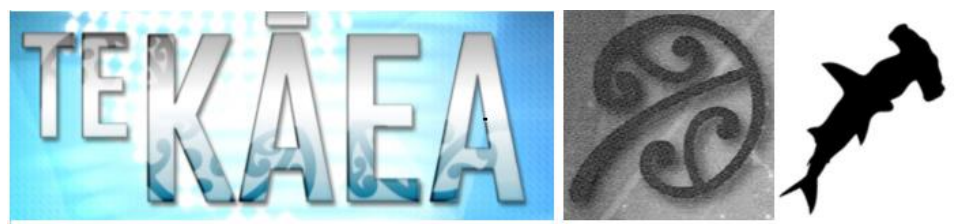

Figure 21: Patterns symbolising hammerhead shark in title lettering compared to a mangōpare (shark) design and a mangōpare silhouette. 
At the five-second mark, we hear a short, sharp, accented orchestral chord that calls for attention. The vision switches to a long shot of the presenter, who is standing (Figure 22); the eye-level frame, his balanced stance and his dark suit bring a formal, corporate air to proceedings. However, the large, glossy desk of mainstream news is absent, and forms no part of the bulletin. We might speculate that Māori news titles eschew the desk as placing a barrier between presenter and receiver in this figurative whare nui; certainly, in real whare nui, those wishing to speak stand, with no barriers between speaker and listeners (Middleton, 2020).

The wall behind the presenter bears the diamond patterns often seen in tukutuku, a type of geometrical weaving using reed latticework that is used to decorate interior walls in whare nui. As with the kōwhaiwhai of Te Karere, we are being placed inside a Māori environment.

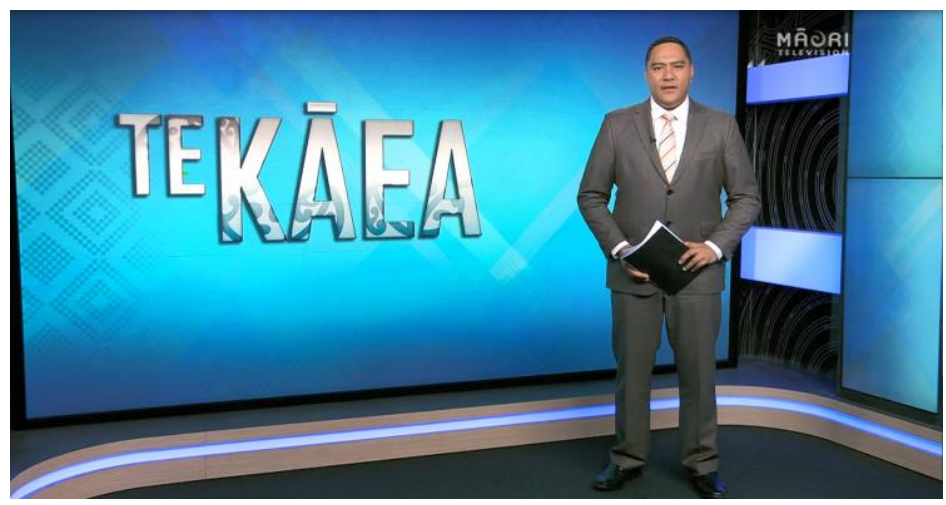

Figure 22: Greeting, Te Kãea, with Piripi Taylor presenting. 
It appears that among the Māori Television design team, which is largely Māori, there is a strong awareness of the meaning-making symbols in tikanga Māori (Māori culture). One of the designers, Titikawhena Ngatai, chose the kōwhaiwhai pattern as she "wanted to portray that the studio was our whare nui". The particular design here is called pātiki, its diamond shape recalling the shape of the pātiki, or flounder fish (Figure 23). The symbolism is that the pātiki provides sustenance for the whole iwi; it is a sign of favourable times.
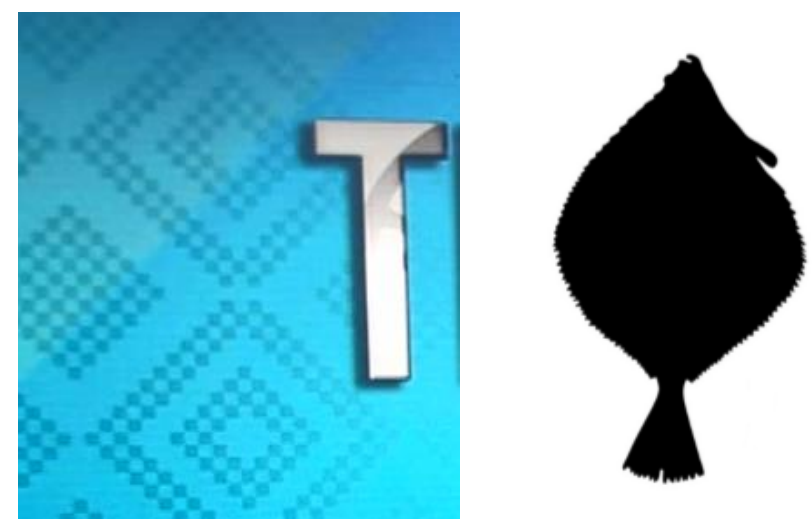

Figure 23: Tukutuku design representing the pātiki (flounder).

According to the designer:

The pātiki pattern ... relates to being able to provide $100 \%$, not only for those close to you, but for the whole iwi [tribe]. I decided to use that pattern for Te Kãea as a way of portraying how we are providing a service ... for our people (T. Ngatai, personal communication, July 31, 2018). 
Just behind the presenter, to the right of the picture, can be seen concentric circles, but these are not related to the concentric circles of broadcasting symbolism discussed earlier. The design is an intersecting double spiral pattern, often used to represent the creation of the world as this is understood by Māori (Jones, 2013).

At this point, the presenter greets the audience with " $\mathrm{E}$ tū takarerewa mai", which is another form of the "Be alert!" sentry's call. The teases, three on this day, run on the video wall behind the presenter (Figure 24). Under the teases, we can just hear punchy orchestral-style chords. The teases are separated by a blue band that travels right to left across the video wall, accompanied by the whirring sound of the pūrerehua (bullroarer), a traditional Māori instrument.

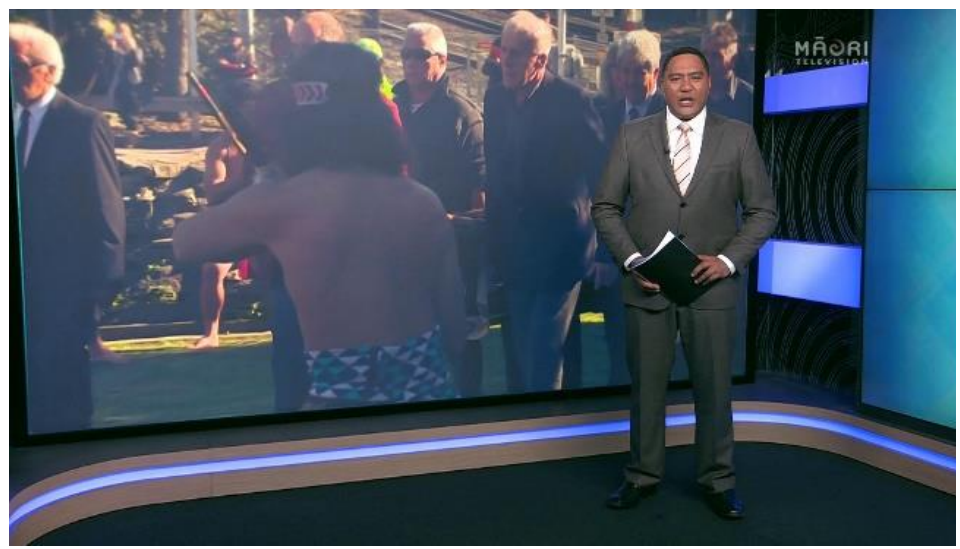

Figure 24: Teases, Te Kāea.

The vision then briefly reintroduces the transparent, spinning globe (Figure 25), which peels away to be replaced by an aerial representation of Aotearoa New Zealand as if from a satellite (Figure 26). Viewers are 

news'

carried at speed from south to north, with kōwhaiwhaitype patterns rising from settlements, among them Dunedin, Christchurch, Wellington, Rotorua, Auckland and Kaitāia.

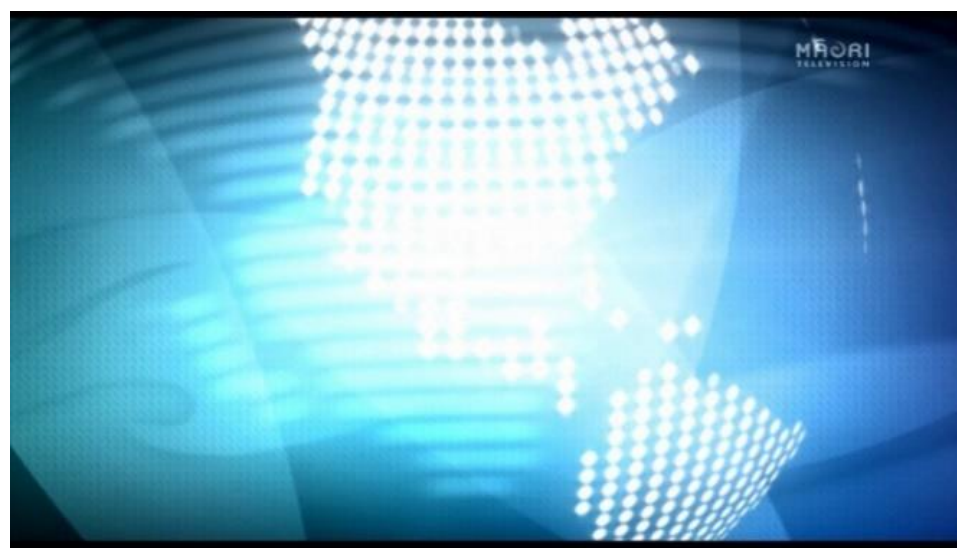

Figure 25: Transparent Earth, Te Kãea

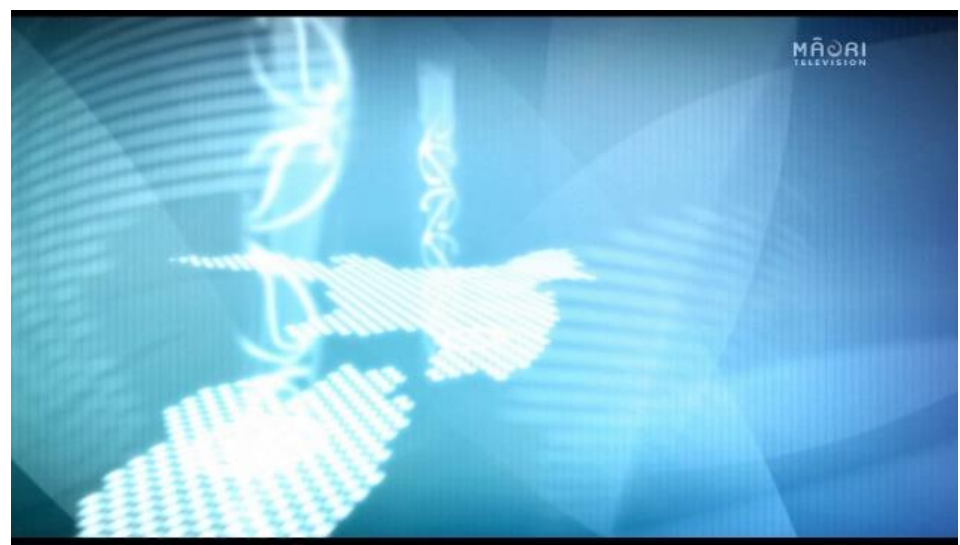

Figure 26: Close of titles, Te Kãea. 
In news titles, reports are often characterised as beams of light rising from cities into space (Machin \& Polzer, 2015, p. 145); "news events shoot out, leaving bright trails, to be delivered at the speed of light". Here, with the kōwhaiwhai added, the lights symbolise the transmission of news through a Māori lens. Designer Ruth Templar said this design aimed to:

reflect the fact that they had reporters in the regions throughout the country and were sharing knowledge and information from all parts of the motu [country] ... the kōwhaiwhai patterns reflect the news, information, knowledge and wairua [feel, mood, essence] being shared with the world through the window of Te Käea. The designs were kept simple, so to not be too specific to one particular iwi [tribe], and be inclusive of all (R. Templar, personal communication, August 6, 2018).

As the viewer is taken north over the top of the country, the screen fades to a bright white and a male voice shouts "Hī! Hā!", an exclamation used in haka and mau rākau as earlier noted. The last note of the theme music is held and decays.

We are returned to the studio and a mid-shot (Figure 27) that approaches the presenter as he says "Kei ngā maunga kōrero huri noa, tēnā rā koutou katoa", which translates as "Speaking mountains of the land, I acknowledge you". 


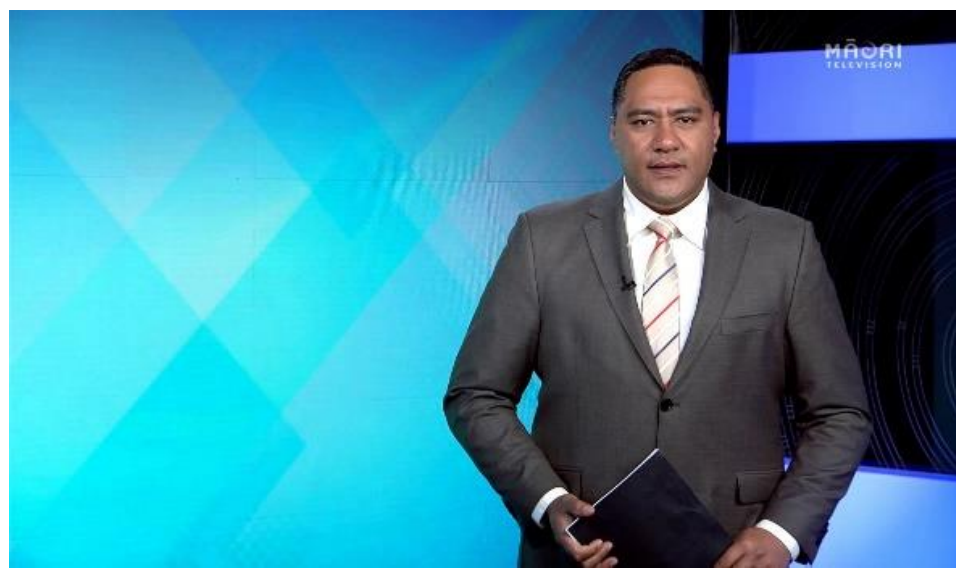

Figure 27: Final frame of Te Kāea.

As earlier described, mountains are symbols of prestige and power; in likening viewers to peaks, the presenter ennobles viewers. As he speaks, a caption appears with his name and the camera draws closer to frame him from the waist up. On the video wall behind, drifting downwards are diamond shapes in blue that recall the earlier tukutuku pattern.

\section{Discussion and conclusion}

The literature review focused on the denotive and connotative properties of news titles in the AngloAmerican tradition. Comparison to the Aotearoa New Zealand news bulletin 1 News shows that the latter largely reproduces the musical and visual signs and symbols of that Anglo-American tradition in order to frame itself as a site of power and authority. A necessary departure is the bulletin's situation of itself in Aotearoa 
New Zealand, evidenced by images of local, recognisable, manmade landmarks.

Analysis of meaning-making in the opening titles of Te Kāea and Te Karere show that they don't stray too far from accepted tropes, lest that compromise their function as signposts to the news. However, they need to differentiate themselves from their English-language counterparts to be clearly identifiable to a Māori audience, and they do this by indigenising elements of their titles.

While 1 News presents us with cityscapes and other representations of Aotearoa New Zealand as a modern capitalist society, Te Karere instead constructs a traditional narrative of Māori identity. Such a construction, wrote McIntosh (2005), can be characterised by "particular identity hooks" (p. 77). These are whakapapa (knowledge of one's genealogy, which includes a strong sense of where one's tūrangawaewae or "place to stand" is); mātauranga Māori (Māori knowledge), and proficiency in te reo Māori and tikanga (customs and practices). The titles of Te Karere present us with an essentialist view of Māori identity - that is, a view that assigns fixed attributes to Māori - subsuming the reality that many Māori do not know their whakapapa, speak te reo or practice "traditional" forms of cultural expression (McIntosh, 2005).

Both Te Karere and Te Käea place the viewer firmly in a traditional Maori space through the use of kōwhaiwhai and tukutuku patterns, artistic expressions of identity in abundance inside Māori meeting houses. Te Karere, in particular, reinforces the central place of the meeting house in Māori identity by depicting the exteriors of two. Notably, both whare nui are filmed from a low angle, 
subordinating the viewer to a potent symbol of the collective. In Te Karere titles, we see three pillars of pepeha - mountain, water and marae - reinforcing an essentialist construction of Māori identity and inviting the viewer to share it.

Te Kāea opens and closes its titles with that instantly recognisable symbol of television news - the spinning globe from a high angle. While Te Kāea employs kōwhaiwhai to draw us into a figurative whare nui, the patterns used on them appear to represent the virtues the show wishes to embody: the persistence and tenacity of the shark and provision for all embodied in the flounder. Turning to music, the themes of both Te Karere and Te Kāea replace western instruments with their Māori equivalents, such as the kāea for the brass trumpet. Crucially, both sets of titles make conspicuous the human voice, reflecting the oral tradition that underpins Māori cultural expression. In Te Karere, we hear the male voice as it is often used in Māori culture to project power and authority: in the sentry's call "Kia hiwa rā!" and the shouted "Hīl" and “"Hī! Hā!” of a kaihaka (male performer) or someone engaged in mau rākau (Māori weaponry). The inclusion of voices above the synthesised music reminds us that Māori culture is oral (Rewi, 2004); in a world of modern technology, where any sound can be made by machines, the human voice remains important. This is emphasised by presenters greeting their audiences with the sort of metaphorical language commonly associated with the "newsmaking" of public oratory, ennobling listeners and setting a formal tone (Rewi, 2010).

In their closing frames, both Te Karere and Te Käea titles suggest that while Māori audiences hold fast to traditional ways of seeing, being and doing, we are not 
stuck in a rose-tinted past; we have embraced the tools of techniques of broadcasting technology to tell our own stories and embrace the possibilities of an increasingly digital world. In Te Karere, a building whose design has not changed in centuries is juxtaposed with the relatively recent Sky Tower; in Te Kãea, we sail in space above Aotearoa New Zealand, with ancient patterns configured in spotlights rising to meet us. The presenters are still, calm and indigenous anchors amidst swirling graphics and urgent music, their demeanour sending the message that they are comfortably in control of technology.

In conclusion, in order to be understood as a news show, the titles of Māori-language news opening titles retain many of the same tropes and signposts common to AngloAmerican new titles; these are now an international shorthand ingrained in English-language media practice. However, as has been previously reported (Middleton, 2020), Māori news is not a mere translation of what is produced by mainstream news for the masses; it is news for those who identify as Māori, and the titles need to make that clear. With the symbolism of both mainstream and Māori culture to draw on, this expression of cultural hybridity (Grixti, 2011) emerges from a broad cultural palette. By weaving together globally recognised symbols of news titles with cultural references deeply embedded in Māori identity, language and culture, the opening titles of Te Karere and Te Käea represent themselves as the news by Māori, for Māori, in a world shaped by Māori values and aspirations.

\section{Acknowledgements}

Many thanks to Dr Sarah Baker and Dr Helen Sissons of the School of Communication Studies, Auckland 
University of Technology, for their suggestions to improve this article. Thanks also to Jacob Slack, Arana Taumata and Brent McAnulty (TVNZ); Linda Moana, Maramena Roderick, Luiz Bond, Titikawhena Ngatai and Ruth Templar (MTS); and composers Jim Hall and Joel Haines. 


\section{References}

Adsett, S., Graham, C. \& McGregor, R. (1992). Kowhaiwhai arts. University of Waikato.

Allan, S. (2010). News culture. McGraw-Hill, Open University Press.

Allen, G. (2011). Intertextuality (2nd ed.). Routledge.

Aslam, M. (2006). Are you selling the right colour? A crosscultural review of colour as a marketing cue. Journal of Marketing Communications, 12(1), 15-30. https://doi.org/10.1080/13527260500247827

Auckland University of Technology (n.d.) Ngā Wai o Horotiu Marae.

Auckland.

https://sprinz.aut.ac.nz/_data/assets/pdf_file/0011/1 50230/Nga-Wai-o-Horotiu-Marae-booklet.pdf.

Bakhtin, M. M. (1986). Speech genres and other late essays. (C. Emerson \& M. Holquist, Eds., V. McGee, Trans.). University of Texas Press.

Barthes, R. (1972). Mythologies. Noonday Press.

Belgrave, M., Kawharu, M., \& Williams, D. (Eds.). (2005).

Waitangi revisited: Perspectives on the Treaty of Waitangi (2nd. ed). Oxford University Press.

Bezemer, J. (2014). Multimodal transcription: A case study.

In S. Norris \& C. D. Maier (Eds.), Interactions, Images and Texts: A reader in multimodality (pp. 155-169). De Gruyter Mouton.

Best, E. (1976). Games and pastimes of the Maori. AR Shearer. http://nzetc.victoria.ac.nz/tm/scholarly/teiBesGame-t1-body-d9-d1-d6.html

Bignell, J. (2002). Media semiotics: An introduction (2nd ed.). Manchester University Press.

Born, E. (2015). A little history of the wireless icon. https://medium.com/palais-des-beaux-arts-wien/alittle-history-of-the-wireless-icon-b50741b01da6 
Boyd, A., Stewart, P., \& Alexander, R. (2012). Broadcast journalism: Techniques of radio and television news. Taylor \& Francis.

Burwell, C. (2003). Music at six. http://cbb4.com/projects/News_Music.shtml

Carter, C. \& Allan, S. (2009). The visual culture of television news. In R. Howells and R. W. Matson (Eds.), Using visual evidence (1st ed., pp. 139-152). McGraw-Hill Education.

Cook, N. (2000). Music: A very short introduction. Oxford University Press.

Cooke, D. (1959) The language of music. Oxford University Press.

Cooke, L. (2005). A visual convergence of print, television, and the internet: Charting 40 years of design change in news presentation. New Media \& Society, 7(1), 22-46. https://doi.org/10.1177/1461444805049141

Creswell, J. W. (2013). Qualitative research and design: Choosing among five approaches (3rd ed.). Sage.

Cubitt, S. (2006). TV news titles: Picturing the planet. Jump Cut: A review of contemporary media, (48). https://www.ejumpcut.org/archive/jc48.2006/CubittG1 obe/tvnews2.html

Day, P. (1990). The making of the New Zealand Press: A study of the organizational and political concerns of New Zealand newspaper controllers, 1840-1880. Victoria University Press.

Deaville, J. (2007). The sounds of American and Canadian television news after 9/11: Entoning horror and grief, fear and anger. In: J. Ritter \& J. Daughtry (Eds.), Music in the post-9/11 world (pp. 43-70). Routledge.

Deaville, J. (2009). TV news music. In: G. Harper (Ed.), Sound and music in film and visual media: An overview (pp. 612-616). Continuum. 
Eldridge, J. and Philo, G. (1995). Glasgow Media Group reader. Routledge.

Fairclough, N. (2003). Analysing discourse: Textual analysis for social research. Routledge.

Fiske, J. (2010). News readings, news readers, in: Television culture (pp. 283-311). Routledge.

Flewitt, R., Hampel, R., Hauck, M., \& Lancaster, L. (2009). What are multimodal data and transcription? In The Routledge handbook of multimodal analysis (pp. 40-53). Routledge.

Flintoff, B. (2004). Taonga pūoro singing treasures: The musical instruments of the Mãori. Craig Potton.

Fox, D. (2002). Honouring the Treaty: Indigenous television in Aotearoa. In J. Farnsworth \& I. Hutchison (Eds.), New Zealand Television: A Reader (pp. 260-269). Dunmore Press.

Gardiner, W. (2007). Haka: A living tradition (2nd ed.). Hachette Livre.

Gorbman, C. (1987). Unheard melodies: Narrative film music. BFI, Indiana University Press.

Graddol, D. (1994). The visual accomplishment of factuality. In D. Graddol \& O. Boyd-Barrett (Eds.), Media texts, authors and readers: A reader (pp. 136-157). Multilingual Matters in association with The Open University.

Grixti, J. (2011). Indigenous media values. In M. Fackler \& R. S. Fortner (Eds.), The handbook of global communication and media ethics (pp. 242-363). WileyBlackwell.

Hamilton, A. (1901). Maori Art. New Zealand Institute.

Haraway, D. (1991). Simians, cyborgs, and women: The reinvention of nature. Taylor \& Francis.

Henry, E., \& Pene, H. (2001). Kaupapa Maori: Locating indigenous ontology, epistemology and methodology in 
the academy. Organization, 8(2), 234-242. https://doiorg.ezproxy.aut.ac.nz/10.1177/1350508401082009

Higgins, R., and Moorfield, J. (2004). Ngā Tikanga o te marae. In $\mathrm{Ki}$ te whaiao: An introduction to Māori culture and society, (pp. 73-84). Pearson.

Hollings J., Hanusch, F., Balasubramanian R., and Lealand, G. (2016). Causes for concern. Pacific Journalism Review, 22(2), 122-138.

Holmes, J. (2003). Narrative structure: Some contrasts. In C.B. Paulston \& G. R. Tucker (Eds.), Sociolinguistics: The essential readings (1st ed., pp. 114-138). Blackwell.

Jewitt, C. (2009). An introduction to multimodality. In C. Jewitt (Ed.), The Routledge Handbook of Multimodal Analysis (pp. 14-27). Routledge.

Jewitt, C., Bezemer, J. and O'Halloran, K. L. (2016). Introducing multimodality. Routledge.

Judd, T. (2015, February 18). The manipulative power of TV news music. The Listeners' Club. http://thelistenersclub.com/2015/02/18/themanipulative-power-of-tv-news-music/

Kandinsky, W. (2010). Concerning the spiritual in art. MobileReference.com.

Kāretu, T. (1993) Haka! The dance of a noble people. Reed.

Keller, P.E., and Schubert, E. (2011). Cognitive and affective judgements of syncopated musical themes. Advances in Cognitive Psychology, 7 , $142-156$. https://doi.org/ 10.2478/v10053-008-0094-0

Kern, R. (2015). Toward a relational pedagogy. In Language, literacy, and technology (pp. 233-260). Cambridge 
University

Press.

https://doi.org/10.1017/CBO9781139567701.012

Kress, G., \& Van Leeuwen, T. (2002). Colour as a semiotic mode: Notes for a grammar of colour. Visual Communication, 1(3), 343-368.

Lloyd, P.R. (2002). Graphic design on UK terrestrial television \& the effects of multi-channel growth. https://paulrobertlloyd.com/articles/2002/06/disserta tion

Machin, D. (2007). Introduction to multimodal analysis. Hodder Arnold.

Machin, D. (2010). Analysing popular music: Image, sound and text. Sage.

Machin, D. (2011). Sound and music as communication: A social semiotic approach. https://semioticon.com/sio/courses/sound-and-musicas-communication-a-social-semiotic-approach/

Machin, D., and Polzer, L. (2015) Visual journalism. Palgrave Macmillan.

McCuhil, F. (n.d.) Definitions of camera angles shots. https://itstillworks.com/definitions-camera-angleshots-1185.html.

McIntosh, T. (2005). Maori identities: Fixed, fluid, forced. In J. H. Liu, T. McCreanor, T. McIntosh, \& T. Teaiwa (Eds.), New Zealand identities: Departures and destinations (pp. 38-51). Victoria University Press.

Mead, H. (2003). Tikanga Māori: Living by Mãori values. Huia.

Middleton, A. (2020). Kia hiwa rā! The influence of tikanga and the language revitalisation agenda on the practices and perspectives of Māori journalists working in reo-Māori news [Doctoral thesis, Auckland University of 
Technology].

https://openrepository.aut.ac.nz/handle/10292/13286

Middleton, J. (2010). Ka rangona te reo: The development of Māori-language television broadcasting in Aotearoa New Zealand. Te Kaharoa, 3(1), 146-176. https://doi.org/10.24135/tekaharoa.v3i1.122

Mitira, T.H. (1944). Tama-te-kapua. In Takitimu. http://nzetc.victoria.ac.nz/tm/scholarly/tei-MitTaki-t1body-d1-d9-d2.html

Morse, M. (1998). Television graphics and the virtual body: Words on the move. In: Virtualities: Television, media art, and cyberculture, Theories of contemporary Culture (pp. 71-98). Indiana University Press.

Mulholland, M., and Bargh, B. (2015). Marae: The heart of Māori culture. Huia Publishers, New Zealand Māori Arts and Crafts Institute.

Orbell, M. (1985). The Natural world of the Maori. Collins and David Bateman.

Jones, P. T. H. (2013). He tuhi mārei-kura A treasury of sacred writings: A Māori account of the creation, based on the priestly lore of the Tainui people. Aka \& Associates.

Pihama, L., Cram, F., \& Walker, S. (2002). Creating methodological space: A literature review of kaupapa Māori research. Canadian Journal of Native Education, 26(1), 30-43.

Profita, H. (2006). The hills are alive with the sound of newsic. In: CBS News.

https://www.cbsnews.com/news/the-hills-are-alivewith-the-sound-of-newsic/

Randel, D. (2003). The Harvard dictionary of music (4th ed.). Harvard University Press. 
Reedy, T.M. (2009). Ngāti Porou - Tribal boundaries and resources. In Te ara: The encyclopedia of New Zealand. https://teara.govt.nz/en/19663

Rewi, P. (2004). Ko te waihanga me nga wehewehenga o te whaikorero: The structural system of whaikorero and its components. Junctures, 2(2004), 17-32.

Rewi, P. (2010). Whaikōrero: The world of Māori oratory. Auckland University Press.

Selby, K., and Cowdery, R, (1995). How to study television. Macmillan.

Smith, L. T. (2012). Decolonizing methodologies: Research and indigenous peoples (2nd ed.). Otago University Press.

Tagg, P. (1982). Nature as a musical mood category. https://www.tagg.org/articles/xpdfs/nature.pdf

Tan, S. (2014). Multimodal constructions of factuality and authenticity in TV-news bulletins. In S. Norris \& C. D. Maier (Eds.), Interactions, images and texts: $A$ reader in multimodality (pp. 299-309). Walter de Gruyter.

Taylor, D. (2017). Six o'clock soundtrack. Gimlet Media. https://www.gimletmedia.com/every-little-thing/sixoclock-soundtrack

The Haka: New Zealand icon (n.d.) https://media.newzealand.com/en/story-ideas/thehaka-new-zealand-icon/

Thompson, W., and Balkwill, L. (2010). Cross-cultural similarities and differences. In Juslin P (ed) Handbook of music and emotion: Theory, research, applications (pp. 755-788). Oxford University Press.

Thussu, D. (2003). Live TV and bloodless deaths: War, infotainment and 24/7 news. In: D. Thussu D \& D. Freedman, (Eds.), War and the media: Reporting conflict 24/7 (pp. 117-132). Sage.

TVNZ brand guide. (n.d.). https://vimeo.com/223727283 
van Leeuwen, T. (1999). Speech, music, sound. Macmillan. van Leeuwen, T. (2012). The critical analysis of musical discourse. Critical Discourse Studies, 9(4), 319-328. https://doi.org/10.1080/17405904.2012.713204

Venuto, D. (2016). TVNZ looks to bring the family together with branding update. http://stoppress.co.nz/news/tvnz-looks-bring-familytogether-branding-update

Waitangi Tribunal. (1986). Report of the Waitangi Tribunal on the te reo Maori claim (Wai 11). Department of Justice.

Walker, R. (2004). Ka whawhai tonu mātou: Struggle without end. Penguin.

Walter, R., \& Reilly, M. (2018). Ngā hekenga waka: Migration and early settlement. In L. Carter, S. Duncan, G. Leoni, L. Paterson, M. Ratima, M. Reilly, \& P. Rewi (Eds.), Te kōparapara: An introduction to the Māori world (pp. 6786). Auckland University Press.

Williams, J. (2004). Ngā hekenga waka: Canoe migrations. In: T. Ka'ai, J. Moorfield \& M. Reilly (Eds)., Ki te whaiao: An Introduction to Māori culture and society (pp. 26-35). Pearson Longman. 